\title{
Exploration and Analysis of Patriotic Education from the Perspective of Network Ideology and Politics in the New Era
}

\author{
Pengtao Ma* \\ Marxist College, Henan Polytechnic University, Jiaozuo 454003, Henan Province, China \\ *Corresponding author: Pengtao Ma, 211915020007@ home.hpu.edu.cn
}

\begin{abstract}
With the development and application of internet technology, network information has penetrated into all aspects of people's lives, profoundly affecting the ideology, value orientation, and national consciousness of people, especially the youth. It has impacted and brought new challenges to patriotic education in colleges and universities. Effectively establishing a position for patriotic education from the perspective of network ideology and politics in the new era is a topic of interest. It is of great significance for enhancing college students' patriotism as well as strengthening national self-confidence and identity.
\end{abstract}

Keywords: Network ideology and politics; Patriotic education

Publication date: October 2021; Online publication: October 29, 2021

\section{Introduction}

Patriotic education is an important part of ideological and political education. It is of great significance for cultivating students' patriotism, enhancing patriotism, as well as strengthening national self-confidence and identity. However, with the development and application of the internet and the impact on education, patriotic education has been affected. Therefore, the topic of facing the impact and challenges, as well as effectively establishing a patriotic education position from the perspective of network ideology and politics have become an interest.

\section{Patriotic education in the new era}

Patriotism is the national heart and soul of the Chinese nation, the most important spiritual wealth of the Chinese nation, as well as the powerful spiritual driving force for the Chinese people and the Chinese nation to safeguard national independence and national dignity. At present, socialism with Chinese characteristics has entered a new era, and the great rejuvenation of the Chinese nation is in a critical period. Strengthening patriotic education in the new era is of great and far-reaching significance for inspiring the national spirit, rallying the strength of the whole nation, decisively building a well-off society in an all-rounded way, winning the great victory of socialism with Chinese characteristics in the new era, and realizing the Chinese dream of the great rejuvenation of the Chinese nation ${ }^{[1]}$.

\subsection{Requirements of the new era in regard to patriotic education}

In the new era, patriotic education should be guided by Marxism-Leninism, Mao Zedong Thought, Deng Xiaoping Theory, the important thought of the "Three Represents," the scientific outlook on development, 
and Xi Jinping's Thought on Socialism with Chinese Characteristics for a New Era. All these include dreaming as the theme, enduring in the unity of loving the party, the country, and socialism, persist in focusing on safeguarding the unity of the motherland and national unity, adhering to the foundation, focusing on construction, as well as being persistent to be based in China and facing the world. All these are required in order to confidently teach ideological and political courses in the socialist education with Chinese characteristics ${ }^{[2]}$. The thought of socialism with Chinese characteristics should be fully used in the new era to create souls, educate people, and cultivate patriotic feelings, so that students can consciously integrate patriotism, strong national aspirations, and service for the country into the persistence and development of the cause and construction of socialism with Chinese characteristics in the struggle to become a modern socialist country as well as realize the great rejuvenation of the Chinese nation. In short, internalization by being rooted in the theoretical system of socialism with Chinese characteristics, and externalization by practice in the action of realizing the Chinese dream, so that patriotic education can achieve the unity of value and knowledge.

\subsection{Necessity of online patriotic education}

The first is the requirements of the times for online patriotic education. In order to ensure proper ideological and political work in colleges and universities, it is necessary for patriotic education to adapt to events, advance with the times, and renew in response to situations. It is necessary to use new media and new technologies to ensure a livelier environment, promote the integration of traditional advantages of ideological and political work with information technology, as well as enhance the sense of the times and attractiveness ${ }^{[3]}$. The continuous integration of new media technology into patriotic education is to ensure advancement in view of the changes of the times. In the new era, online patriotic education is a new product of the internet plus education. The characteristics of the internet should be used to stimulate the vitality of education, new media technology should also be used to break the traditional "one word" mode in ideological and political courses, and patriotic education should be integrated with information technology, so that the advantages of new technologies can be better used to strengthen patriotism, the sense of the times, and the attractiveness of ideological education.

The second is the needs of patriotic education in colleges and universities. Patriotic education in the new era should be geared for all people, and its focus should be on young people. If patriotic education is to excel in the new era, the focus should be on the young people, and if patriotic education is to benefit young people, the growth stage of young people should be firmly grasp. At present, the "post-00s" have become the main body in colleges and universities. Their ideological and political situation has shown new characteristics as the country is becoming stronger along with social development and improvement of living standards. Students' political awareness and self-education level have significantly improved as they are increasingly becoming concerned about social development, national affairs, and political issues, gradually changing from their passive acceptance of ideological and political education to an active acquisition and participation. In addition, some of their utilitarian ideas are highlighted. This change is generally beneficial to ideological and political education, but the closer China is to the center of the international arena, the greater the impact of diverse cultural ideas and the more complicated the ideological and political situation for students. In particular, they are the "indigenous people" of the internet as they have grown alongside the internet. The characteristics of the globalization of the internet have a huge impact on their national consciousness, national identity, and patriotic feelings. 


\section{Challenges of the implementation of patriotic education from the perspective of network ideology and politics}

\subsection{Impact of the network environment on patriotic education}

The first is the tendency of "fictitious history" and "extreme populism" to incite negative emotional reactions from the corresponding subjects, which deconstruct the value and significance of the content of online patriotic education ${ }^{[4]}$. Not all information found in cyberspace is for the good, but some are mixed with the malicious guidance of "fictitious history" and "extreme populism." Using the free flow of information and the blind spots of the public's cognition, "fictitious history" strives to distort and slander historical facts, discredit national heroes deliberately, beautify negative historical figures, and wantonly question or even deny the excellent traditional Chinese culture, revolutionary culture, and the society. It is important to reconstruct the ideological connotation and meaning of the content of online patriotic education for youth to avoid damaging the self-esteem and confidence of the majority of netizens in history and culture. "Extreme populism" exaggerates social contradictions in the period of social transformation and the critical period of reform, stimulate grassroots sympathy by selling anxiety, tragic narratives, intensifying contradictions, and peddling misery, as well as confuse young netizens and demonize them, thus destroying their patriotism in reality.

Second, the capital logic with the ultimate goal of capital appreciation has been involved in cyberspace, and it is the impetus behind the negative consequences of "flow-oriented" that cannot be disregarded. Essentially, the core of capital logic is to maximize benefits, promoting "money determinism" and "floworiented," which is essentially "money worship." With the deepening of economic globalization and market economy, capital logic has accelerated its influence on the online public opinion field. Some profit-seeking people are skilled at using the "flow-oriented" characteristic of cyberspace in an attempt to gain benefits and control the trend of public opinions. In fact, the influx of capital into the field of online public opinion is not terrible. What makes people worry is that the "money worship," dominated by capital logic, squeezes the mainstream discourse space of online patriotic education for youth. The "flow-oriented" capital logic advocates the supremacy of consumerism and promotes the fetishism of money, which would undoubtedly dispel the mainstream discourse of online patriotic education for youth, erode their patriotic enthusiasm, and even drive weak-willed youths to fall into capitalist portrayals, thus unable to extricate themselves from the fanatic consumption situation in China.

\subsection{Status quo and difficulties in the implementation of online ideological and political education}

From 2014, Chinese colleges and universities have successively pushed ideological and political courses online, creating a precedent for massive open online courses (MOOCs) to innovate the hybrid teaching model ${ }^{[5]}$. Based on the statistics of China University MOOC - Love Courses Network, as of December 8, 2019 , a total of 302 colleges and universities across the country are cooperating with the website, but only 31 colleges and universities provide online ideological and political courses. According to statistics, 16 colleges and universities have launched undergraduate ideological and political courses, six colleges have launched higher vocational ideological and political courses, one college has launched postgraduate ideological and political courses, six colleges have launched a series of Chinese ideological and political courses, and five colleges have launched online situations and policies. The four core ideological and political courses are undergraduate ideological and political courses from 16 universities and six higher vocational ideological and political courses. The only universities that have launched these four core courses are Peking University, Wuhan University, Nankai University, and Hebei University of Science and Technology. From the above analysis, it can be seen that the current development of network ideological and political courses is still in its infancy, with only a few online courses, single content, and flawed 
systemic construction of network ideological and political courses in colleges and universities.

From the perspective of educational content and methods, the focus is on Marxism-Leninism, Mao Zedong Thought, Deng Xiaoping Theory, the important thought of "Three Represents," the scientific outlook on development, and Xi Jinping's Thought of Socialism with Chinese Characteristics in the New Era in combination with Chinese history and excellent traditional culture, the great national spirit and characteristic culture as the content, as well as the integration of new media technology to create excellent patriotic educational audios, videos, pictures, articles, etc. using network features to effectively spread online learning, so that students can achieve theoretical recognition and enhance their enthusiasm for learning.

From the perspective of the subject of education, the subject of patriotic education in network ideological politics is not only restricted to teachers. All creators of patriotic education content are subjects. Education is pedagogical, which mainly reflects the subject's cognitive level, value orientation, and ideological appeal. Whether it is in the form of audios, videos, or pictures, it reflects a person's knowledge level, value orientation, and ideological appeal. Currently, there is no mandatory documented regulation for the content of online patriotic education. It has immeasurable freedom, and its educational effectiveness varies. Therefore, students face the issue of low value in educational works or rough works when selecting learning contents.

\section{Suggestions on the implementation of patriotic education from the perspective of network ideology and politics}

\subsection{Adhere to the main content of online patriotic education}

In terms of educational content, it is necessary to adhere to Marxism-Leninism, Mao Zedong Thought, Deng Xiaoping Theory, the important thought of "Three Represents," the scientific outlook on development, and Xi Jinping's Thought on Socialism with Chinese Characteristics in the New Era as the center. In addition, it is also important to promote education on the in-depth development of socialism with Chinese characteristics and the Chinese dream, national conditions, and situation policy while vigorously promoting the national spirit and the spirit of the times. Other than that, extensively promoting the education on the party's history, national history, reform and opening-up, motherland's reunification, national unity and progress, national security, and national defense is also essential in patriotic education to inherit and carry forward the excellent traditional Chinese culture. It is important to strengthen beliefs with theory, use knowledge to refute miscellaneous information from the internet, and make the theoretical system a beacon of the times. Students can then confidently and bravely portray their love for the party, their country, and socialism in the diversified cyberspace.

\subsection{Enrich the forms of online patriotic education}

In order for patriotic education to fill the network space, it is important to produce and promote audios, videos, online articles, documentaries, micro movies, etc. that conform to the content of patriotic education and are suitable for network dissemination. Patriotic digital construction projects should be implemented, and the organic integration of patriotic education, red tourism, and network communication should be promoted. In carrying out online patriotic education, the means of communication media should be innovated, social media should be actively used along with videos, websites, mobile clients, and other communication platforms, new technologies and products such as virtual reality, augmented reality, and mixed reality should also be considered. The role of "learning to power the country" should be used as the patriotic propaganda in education. In addition, it is necessary to strengthen the guidance of online public opinion, conduct comprehensive management in accordance with laws and regulations, as well as guide 
netizens to consciously resist using words and deeds that may damage the national honor and deny China's excellent traditional culture. In this way, the accumulation of positive energy online can be realized.

\subsection{Strengthen the construction of the main body of online patriotic education}

Let those who have faith speak of faith, and those who have patriotic feelings to speak of patriotism. It is important to strengthen the construction of the main body of online patriotic education in accordance with the requirements of strong politics, deep feelings, new thinking, self-discipline, and upright personality; strengthen the construction of the online patriotic education team, integrate emotions in teaching, as well as integrate values in knowledge. In the process, the reform and innovation of online patriotic education should be promoted, love and education should be unified, the affinity of online patriotic education should be enhanced, and students should be encouraged to establish national awareness, raise their national selfconfidence and identity, as well as cultivate patriotic feelings.

\section{Conclusion}

In the context of the new era, online ideological and political education is playing an increasingly important role. Patriotism is an important part of ideological and political education. Strengthening online patriotic education is not only the needs of the education, but also to respond to the network environment. Therefore, to strengthen the reform and innovation of online patriotic education, it is necessary to begin by adhering to the main content of online patriotic education, enrich the forms of online patriotic education, and strengthen the construction of the main body of online patriotic education.

\section{Disclosure statement}

The author declares that there is no conflict of interest.

\section{References}

[1] The Central Committee of the Communist Party of China and the State Council, 2019, Implementation Guidelines for Patriotism Education in the New Era, People's Publishing House, Beijing, 1.

[2] 2019, Xi Jinping Presided Over the School's Ideological and Political Theory Course Teachers' Symposium, Emphasizing: Use the Socialist Thought with Chinese Characteristics in the New Era to Cast the Soul, Educate the People, Implement the Party's Educational Policy, and Implement the Fundamental Task of Cultivating Morality and Cultivating People. People's Daily, (1).

[3] 2016, Xi Jinping Emphasized at the National Conference on Ideological and Political Work in Colleges and Universities: Putting Ideological and Political Work Through the Whole Process of Education and Teaching to Create a New Situation for the Development of Higher Education in My Country. People's Daily, (1).

[4] Zhao L, 2019, Challenges and Countermeasures of Youth Online Patriotism Education in the "PostTruth" Era. Chinese Youth Studies, (05): 11-16.

[5] Zhu G, 2019, Research on the Blended Teaching Reform of Ideological and Political Courses in Colleges and Universities Based on MOOC. Education Review, (7): 133-138. 